\title{
Crowdfunding sebagai Bentuk Budaya Partisipatif pada Era Konvergensi Media: Kampanye \#BersamaLawanCorona (Kitabisa.com)
}

\author{
Dhyayi Warapsari \\ dhyayi.warapsari81@ui.ac.id \\ Universitas Indonesia, J1. Salemba Raya 4, Jakarta, Indonesia
}

Submitted: 24 March 2020 Revised: 13 April 2020 Accepted: 13 Mei 2020

\begin{abstract}
Abstrak
Internet dan teknologi digital memberikan kemudahan bagi manusia untuk melakukan berbagai macam aktivitas yang semula dilakukan secara manual, bertatap muka, dan dengan keterbatasan jarak dan waktu. Dengan adanya teknologi-teknologi baru pada era digital yang terkoneksi dengan jaringan internet, manusia dapat terhubung dengan mudah meskipun terpisah oleh jarak. Akan tetapi, semua teknologi tersebut tidak memiliki arti tanpa ada manusia sebagai pengguna. Keberadaan dan kegunaan teknologi tergantung pada institusi dan budaya yang memungkinkan teknologi tersebut bertahan sehingga penting untuk mengkaji budaya partisipatif yang melingkupi teknologi itu. Ada empat bentuk budaya partisipatif yang dapat dikaji, yaitu afiliasi, ekspresi, pemecahan masalah secara kolaboratif, dan sirkulasi. Salah satu masalah yang dihadapi oleh bangsa Indonesia pada 2020 adalah masalah pandemi Covid-19. Meningkatnya jumlah orang yang terdiagnosis positif Covid-19 dan korban meninggal menimbulkan kepanikan di kalangan masyarakat sehingga banyak orang yang membeli alat-alat kesehatan, seperti masker dan hand sanitizer, untuk melakukan pencegahan. Hal itu menyebabkan kelangkaan stok dan peningkatan tajam harga alat-alat kesehatan, padahal tenaga medis yang secara langsung menangani para pasien sangat membutuhkannya. Di tengah kesulitan dana untuk mencegah dan mengatasi penyebaran Covid-19, muncul kampanye penggalangan dana \#BersamaLawanCorona yang dilaksanakan oleh platform crowdfunding Kitabisa.com yang bekerja sama dengan beberapa partners. Tulisan ini merupakan sebuah conceptual paper dengan metode kualitatif literature review yang berusaha membangun argumen hubungan logis antara konsep crowdfunding, budaya partisipatif, dan konvergensi media yang dikaitkan dengan kampanye penggalangan dana \#BersamaLawanCorona yang diselenggarakan oleh Kitabisa (kitabisa.com) untuk membantu mengatasi masalah pandemi Covid-19 di Indonesia.
\end{abstract}

Kata kunci: budaya partisipatif; crowdfunding; donasi online; konvergensi media; media digital

\section{Crowdfunding as A Form of Participatory Culture in Media Convergence Era: \#BersamaLawanCorona Campaign (Kitabisa.com)}

\begin{abstract}
The internet and digital technology provide convenience for humans to carry out various activities that were originally carried out manually, face-to-face, and with time and distance limitations. With new technologies in the digital age connected to the internet, people can easily connect to each other even though separated by distance. However, all of these technologies are meaningless without humans as users. The existence and usefulness of technology depends on the institution and culture that enable the technology to survive so that it is important to study the participatory culture that surrounds the technology. There are four forms of participatory culture that can be studied, namely affiliations, expressions, collaborative problem-solving, and circulations. One of the problems being faced by Indonesia in 2020 is the Covid-19 pandemic issue. The increasing number of people diagnosed positive for Covid-19 and the death toll has caused panic among the people so that many people buy medical devices, such as masks and hand sanitizers, for prevention. It causes a shortage of stocks and a sharp increase in prices for medical devices, whereas medical personnel who directly deal with patients urgently need it. In the midst of financial difficulties to prevent and overcome the spread of Covid-19, a \#BersamaLawanCorona fundraising campaign was launched by the crowdfunding platform Kitabisa.com in collaboration with several partners. This paper is a conceptual paper with a qualitative literature review method that attempts to build an argument for a logical relationship between the concepts of crowdfunding, participatory culture, and media convergence in the context of \#BersamaLawanCorona
\end{abstract}


fundraising campaign organized by Kitabisa (Kitabisa.com) that help resolve the Covid-19 pandemic problem in Indonesia.

Keywords: participatory culture, crowdfunding, online donation, digital media, media convergence

\section{PENDAHULUAN}

Kemunculan teknologi digital dan internet memungkinkan pelaksanaan kegiatan yang semula dilakukan melalui tatap muka atau cara manual lainnya dengan segala keterbatasan jarak dan waktu menjadi lebih cepat, efisien, mudah, dan tanpa hambatan jarak dan waktu. Salah satu kegiatan yang memanfaatkan teknologi digital dan internet adalah kegiatan penggalangan dana dari masyarakat atau yang dikenal dengan istilah crowdfunding. Menurut Gras, Nason, Lerman, dan Stellini (2017), konsep crowdfunding yang menggunakan platform online sama dengan konsep kegiatan penggalangan dana yang telah lama dipraktikkan jauh sebelum penemuan teknologi digital dan internet atau yang mereka sebut dengan istilah offline crowdfunding. Pada era sebelum kemunculan internet, offline crowdfunding dilakukan melalui tatap muka langsung atau menggunakan media cetak. Pada saat ini, offline crowdfunding masih dilakukan, misalnya melalui konser musik, makan malam, dan lomba maraton untuk amal.

Internet menyediakan alat bagi para penggalang dana untuk mengumpulkan uang secara online sebagai tambahan dari penggalangan dana yang mereka lakukan secara offline (Dresner, 2014). Gras dkk. (2017) menyebut kegiatan offline crowdfunding dan online crowdfunding saling melengkapi. Pada era internet, kegiatan offline crowdfunding memanfaatkan internet untuk menyebarkan informasi mengenai kegiatan tersebut. Kegiatan penggalangan dana melalui platform online juga membutuhkan pembangunan kepercayaan secara offline karena orang cenderung mau berdonasi online jika mereka dapat mempercayai penyelenggaranya. Penggunaan platform offline dan online secara bersamaan dapat membangun sebuah komunitas yang lebih kuat dan meningkatkan kemungkinan orang untuk berdonasi karena orang cenderung ingin berdonasi untuk membangun hubungan dengan orang lain (Gras et al., 2017).

$$
\text { Perkembangan teknologi }
$$

memunculkan beragam pilihan media yang menyebabkan semakin beragamnya cara orang mengakses informasi dan berinteraksi melalui internet. Pada era Web 1.0, orang menggunakan web hanya untuk mencari informasi dan melakukan interaksi (Dresner, 2014). Pada era Web 2.0, orang dapat memanfaatkan web untuk berbagi informasi, berkomunikasi dengan teman, dan bahkan membangun hubungan online dengan orang yang tidak pernah ditemui (Dresner, 2014). Kehadiran teknologi mobile memungkinkan orang untuk mengakses informasi di internet dari mana saja, baik melalui aplikasi atau situs web versi mobile (Wong, 2012). Informasi yang diakses pun memiliki format yang lebih beragam, seperti teks tertulis, video, gambar, foto, dan animasi.

Seiring dengan perkembangan teknologi yang semakin beragam itu, terjadi konvergensi media yang menggabungkan teknologi-teknologi itu untuk satu tujuan yang terarah (Trivedi \& Thaker, 2001). Konvergensi media 
mendorong perubahan di masyarakat, seperti gaya hidup, pola perilaku, dan strategi pasar (Trivedi \& Thaker, 2001). Akan tetapi, menurut Jenkins dkk. (2009), teknologi tidak dapat melakukan apa pun tanpa adanya pengguna. Pemanfaatan teknologi dikatakan oleh Jenkins dkk. (2009) tergantung pada konteks budaya. Kemunculan teknologi baru mengubah hubungan manusia dengan teknologi yang sudah ada sebelumnya dan aktivitas yang terkait, tetapi aktivitas yang diakibatkan oleh teknologi baru itu akan bertahan dan menyebar hanya jika ada budaya yang mendukung terjadinya penyebaran aktivitas itu (Jenkins et al., 2009).

Perkembangan teknologi digital dan internet pada era Web 2.0 ini didukung oleh budaya partisipatif yang muncul sebagai respons kemunculan teknologi-teknologi baru yang memungkinkan orang biasa untuk mengarsipkan, menganotasi, menyediakan, dan menyebarkan konten media dengan cara yang lebih berpengaruh (Jenkins et al., 2009). Menurut Jenkins dkk. (2009), budaya partisipatif memiliki empat bentuk, yaitu afiliasi dengan komunitas online, ekspresi diri dengan membuat karya baru, pemecahan masalah secara kolaboratif, dan sirkulasi informasi.

Kampanye penggalangan dana \#BersamaLawanCorona yang dilaksanakan oleh salah satu platform online crowdfunding di Indonesia, Kitabisa (kitabisa.com), merupakan salah satu bentuk budaya partisipatif dalam usaha mencari solusi bagi masalah pendanaan untuk menangani krisis pandemi Covid-19 di Indonesia pada 2020. Data laporan di laman utama kampanye \#BersamaLawanCorona (galangdana.kitabisa.com/partners/bersa malawancorona) per 12 April 2020 menunjukkan bahwa kampanye tersebut telah berhasil mengumpulkan dana lebih dari 101 miliar dari 3.300 lebih penggalang dana. Jumlah donasi dan penggalang dana itu mengalami peningkatan yang cukup drastis dalam waktu kurang dari sebulan di mana per 20 Maret 2020 jumlah donasi masih di kisaran 14 miliar dari 290 penggalang dana. Penyebaran informasi mengenai penggalangan dana melalui kampanye \#BersamaLawanCorona itu disebarkan melalui berbagai macam media, seperti televisi, kegiatan offline, kanal berita online, dan media sosial dengan menggunakan berbagai format media, seperti teks, video, dan gambar. Tulisan ini menggunakan kampanye crowdfunding \#BersamaLawanCorona tersebut sebagai konteks untuk menjelaskan kaitan logis antara konsep crowdfunding, budaya partisipatif, dan konvergensi media.

Hasil penelusuran penelitianpenelitian terdahulu memperlihatkan bahwa penelitian mengenai crowdfunding memiliki beberapa topik yang dominan seputar motivasi orang berpartisipasi dalam crowdfunding (Aziz, Nurwahidin, \& Chailis, 2019; Choy \& Schlagwein, 2016; Gleasure \& Feller, 2016; Sitanggang, 2018), penggunaan platform crowdfunding (Hutami \& Irwansyah, 2019; Ibrahim, 2013; Sitanggang, 2018), gotong royong (Gea, 2016; Irfan, 2016), pemanfaatan crowdfunding untuk pendanaan (Abdillah \& Danial, 2015; Adiansah, Mulyana, \& Fedryansyah, 2016; Arifin \& Wisudanto, 2017), dan hukum 
(Budiman \& Octora, 2019; Chang, 2018; Hariyani \& Serfiyani, 2015).

Penelitian-penelitian terdahulu mengenai crowdfunding belum ada yang menjelaskan secara eksplisit kaitan antara konsep crowdfunding, budaya partisipatif, dan konvergensi media. Tulisan ini diharapkan dapat menjadi jembatan bagi penelitian-penelitian selanjutnya yang ingin meneliti topik crowdfunding dan mengaitkannya dengan konsep budaya partisipatif dan konvergensi media.

\section{METODE PENELITIAN}

Tulisan ini merupakan sebuah conceptual paper yang menggunakan metode kualitatif literature review. Conceptual paper tidak menghasilkan data karena fokus pada pembentukan argumen logis untuk mengintegrasikan dan mengajukan hubungan antarkonstruksi, bukan fokus pada pengujian secara empiris (Gilson \& Goldberg, 2015). Conceptual paper tidak menghasilkan teori baru pada level konstruksi, tetapi menjembatani teoriteori yang sudah ada, menghubungkan karya-karya dari disiplin ilmu yang berbeda, menyediakan kajian dari berbagai level, dan meluaskan wawasan pikiran (Gilson \& Goldberg, 2015). Conceptual paper yang baik dimulai dari ringkasan mengenai topik pembahasan dan keadaan terkini dari topik itu (state of the science) untuk menentukan apa yang telah diketahui, harus mulai dari mana, dan area apa yang masih harus diteliti (Gilson \& Goldberg, 2015) sehingga metode literature review menjadi pilihan yang tepat.

Tulisan ini berfokus pada pembentukan argumen mengenai hubungan logis antara konsep crowdfunding, budaya partisipatif, dan konvergensi media yang dikaitkan dengan situasi krisis Covid-19 di Indonesia dan berfokus pada kampanye \#BersamaLawanCorona yang diselenggarakan oleh Kitabisa (kitabisa.com). Data mengenai konsepkonsep dikumpulkan dari buku dan jurnal, sedangkan data mengenai kampanye \#BersamaLawanCorona dikumpulkan dari situs berita online, media sosial, dan situs kitabisa.com, baik dari laman utama kampanye \#BersamaLawanCorona (https://galangdana.kitabisa.com/partner s/bersamalawancorona) maupun dari laman kampanye mitra atau partners di bawah kampanye \#BersamaLawanCorona, seperti laman penggalangan dana yang dilakukan oleh keluarga artis Raffi Ahmad, Nagita Slavina, dan Rafathar (https://kitabisa.com/campaign/lindungid aricovid19) dan Dompet Dhuafa (https://kitabisa.com/campaign/ayolawanc orona). Untuk menambah data mengenai platform Kitabisa, peneliti juga menelusuri informasi di laman Tentang Kitabisa (https://kitabisa.com/about-us) dan laman bantuan (https://help.kitabisa.com/), serta mencoba melakukan donasi untuk melihat alur donasi di platform Kitabisa.

\section{HASIL DAN PEMBAHASAN Crowdfunding}

Menurut Belleflamme dkk. (2014), fenomena crowdfunding adalah fenomena yang relatif baru. Konsep crowdfunding disebut oleh Belleflamme dkk. (2014) datang dari konsep yang lebih besar, yaitu crowdsourcing. Dalam crowdsourcing, crowd digunakan untuk mendapatkan ide, pendapat, masukan, dan solusi, sedangkan dalam crowdfunding, hasil spesifik yang 
diharapkan dari crowd adalah dana (Belleflamme et al., 2014; Hemer, 2011).

Belleflamme dkk. (2014: 588) menawarkan definisi crowdfunding sebagai ajakan terbuka, terutama melalui internet, untuk menyediakan sumber daya finansial, baik dalam bentuk donasi atau pertukaran dengan produk yang akan dihasilkan atau dalam bentuk apresiasi lainnya untuk mendukung inisiasi suatu tujuan tertentu. Serupa dengan definisi dari Belleflamme dkk., Dresner (2014: xi) mendefinisikan crowdfunding sebagai kerja sama kooperatif oleh orang-orang yang mengumpulkan uang mereka yang biasanya dilakukan melalui internet untuk mendukung usaha-usaha yang dimulai oleh orang atau organisasi lain. Hal yang perlu menjadi perhatian pada kedua definisi tersebut adalah penyebutan medium untuk melakukan crowdfunding, yaitu 'terutama melalui internet' dan 'biasanya dilakukan melalui internet'. Penyebutan internet mengindikasikan penggunaan teknologi jaringan online dalam melakukan crowdfunding, tetapi kedua definisi tersebut tidak juga menutup kemungkinan penggunaan medium lain karena tidak menyebutkan keharusan penggunaan internet.

Pendefinisian batasan medium dalam konsep crowdfunding, apakah online saja atau juga mencakup offline, menjadi sorotan Gras dkk. (2017). Menurut Gras dkk. (2017), penggalangan dana melalui tatap muka langsung (offline) yang telah ada sebelum penemuan internet memiliki konsep yang sama dengan penggalangan dana melalui interaksi virtual dengan teknologi internet (online) sehingga istilah crowdfunding sebaiknya mencakup offline dan online. Pada tulisan ini, konsep crowdfunding yang digunakan mencakup offline dan online, dengan kecenderungan ke arah penggunaan online sehingga definisi crowdfunding yang digunakan adalah definisi dari Belleflamme dkk. (2014) dan Dresner (2014).

Pengkomunikasian tujuan dan kepentingan crowdfunding dilakukan secara luas dalam sebuah forum terbuka melalui sebuah kampanye oleh pemilik kampanye atau pihak yang bertanggung jawab terhadap penggalangan dana tersebut yang kemudian dievaluasi oleh sekumpulan besar individu yang disebut dengan crowd (Dresner, 2014). Pesan dalam kampanye crowdfunding tidak ditujukan secara khusus untuk khalayak tertentu (Dresner, 2014). Kampanye disebarkan terutama melalui sebuah platform online, lalu didukung oleh penyebaran melalui saluran komunikasi personal lainnya (Choy \& Schlagwein, 2016; Dresner, 2014).

Crowdfunding dapat dilakukan untuk beragam tujuan, mulai dari untuk membantu korban bencana alam, penerbitan buku, membantu modal usaha kecil menengah, hingga kampanye politik (Dresner, 2014). Secara umum, ada dua kategori besar crowdfunding, yaitu crowdfunding yang mengharapkan keuntungan finansial dan crowdfunding yang tidak mengharapkan keuntungan finansial (Dresner, 2014). Dalam semua kategori itu, crowdfunding yang memiliki tujuan sosial menempati peringkat teratas (Dresner, 2014).

Crowdfunding dapat dijalankan dengan beberapa model kampanye (Dresner, 2014), yaitu:

1) Crowdfunding berbasis donasi atau amal. Model ini sering digunakan oleh organisasi nonprofit untuk 
menggalang dana bagi orang-orang yang sedang dalam kesulitan.

2) Crowdfunding berbasis apresiasi (reward). Penggalang dana yang menggunakan model ini menawarkan imbalan nonfinansial yang berwujud, seperti ucapan terima kasih di laman situs, pencantuman nama sebagai sponsor, atau hadiah barang.

3) Crowdfunding berbasis pinjaman. Penggalang dana yang menggunakan model ini menawarkan pengembalian dana yang biasanya disertai dengan bunga dalam jadwal yang ditentukan.

4) Crowdfunding berbasis ekuitas. Penggalang dana yang menggunakan model ini menawarkan kesempatan bagi donatur untuk memiliki saham di perusahaan.

Tren di industri crowdfunding menunjukkan bahwa platform-platform crowdfunding cenderung fokus pada satu model kampanye yang spesifik untuk membantu membangun basis khalayak yang terus datang ke platform itu karena kesamaan nilai yang mereka miliki (Choy \& Schlagwein, 2016; Dresner, 2014). Kesamaan nilai yang dimiliki oleh semua pihak yang terlibat akan membantu platform, penggalang dana, dan khalayak karena komunikasi yang efisien dapat terjadi ketika semua pihak memiliki kesamaan minat (Dresner, 2014). Sebagai contoh, platform crowdfunding yang menjadi fokus pada tulisan ini, yaitu Kitabisa (kitabisa.com) memfokuskan diri pada model crowdfunding berbasis donasi untuk tujuan sosial dan tidak memfasilitasi pemberian reward bagi para donatur.

Pengklasifikasian crowdfunding juga dapat dilakukan berdasarkan karakteristik pembuat kampanye, seperti pengklasifikasian yang dilakukan oleh Hemer (2011), sebagai berikut:

1) Independen dan tunggal di mana penggalangan dana dilakukan oleh individu yang tidak memiliki latar belakang institusi atau organisasi.

2) Embedded di mana penggalangan dana dilakukan oleh organisasi publik atau privat yang telah ada sebelumnya, seperti perusahaan dan pemerintah.

3) Start-up di mana penggalangan dana dilakukan oleh pihak independen yang bertujuan untuk mendirikan sebuah organisasi privat atau publik.

Berdasarkan keterangan yang dikumpulkan dari situs web kitabisa.com, Kitabisa memfasilitasi kampanye yang dilakukan oleh individu, maupun organisasi, seperti perusahaan yang ingin mengajak masyarakat untuk ikut serta dalam kampanye CSR (corporate social responsibility) perusahaan, serta institusi pemerintah dan lembaga swadaya masyarakat (LSM) yang ingin menggalang dana untuk kegiatan sosial.

Pengklasifikasian lain dapat dilakukan berdasarkan strategi pendanaan kampanye crowdfunding yang diatur oleh platform crowdfunding (Dresner, 2014), yaitu:

1) All-or-nothing di mana penggalang dana harus menentukan target jumlah dana yang ingin dicapai dan target waktu pencapaian. Ketika target pengumpulan dana tidak tercapai ketika tenggat waktu yang ditentukan telah berlalu, kampanye dinyatakan gagal dan dana dikembalikan lagi ke para donatur. Contoh platform crowdfunding yang menerapkan allfor-nothing adalah Kickstarter. 
2) Flexible funding di mana penggalang dana akan mendapatkan dana berapa pun yang sudah ia kumpulkan, meskipun target dana tidak tercapai setelah lewat tenggat waktu kampanye. Platform crowdfunding Kitabisa menerapkan sistem flexible funding ini bagi penggalang dana yang memiliki akun terverifikasi.

\section{Crowdfunding pada Era Konvergensi Media}

Konsep crowdfunding di mana organisasi amal menggalang dana dari masyarakat untuk mendanai suatu proyek atau isu filantropis telah ada sejak ribuan tahun lalu (Dresner, 2014; Gleasure \& Feller, 2016). Gras dkk. (2017) menyebut fenomena crowdfunding bukan hal baru dan tidak muncul karena adanya platform teknologi. Sebelum penemuan internet, penggalangan dana dilakukan melalui interaksi langsung atau media cetak, misalnya penggalangan dana untuk pembiayaan Patung Liberty (Gras et al., 2017). Gras dkk. (2017) menyebut penggalangan dana semacam itu dengan istilah offline crowdfunding, sedangkan istilah online crowdfunding digunakan untuk menyebut penggalangan dana yang menggunakan teknologi platform online.

Hingga saat ini, praktik offline crowdfunding masih dilakukan, misalnya melalui acara penggalangan dana berupa konser amal, gala dinner, lomba maraton, dan lain sebagainya (Gras et al., 2017). Gras dkk. (2017) menyebut kegiatan offline crowdfunding dan online crowdfunding saling melengkapi. Orang membagikan informasi tentang offline crowdfunding menggunakan internet sehingga memungkinkan semakin banyak orang mengetahui tentang kegiatan penggalangan dana tersebut. Selain itu, penyebaran informasi tentang offline crowdfunding melalui internet juga dapat membantu membangun reputasi dan kredibilitas penggalang dana sehingga memudahkan penggalang dana ketika mereka hendak menyelenggarakan online crowdfunding karena orang mau berdonasi online jika mereka dapat mempercayai penyelenggaranya (Gras et al., 2017). Penggunaan platform offline dan online dapat membangun sebuah komunitas yang lebih kuat dan dapat meningkatkan kemungkinan orang untuk berdonasi karena orang cenderung ingin berdonasi untuk membangun hubungan dengan orang lain (Gras et al., 2017).

Kemunculan teknologi internet menyediakan alat bagi organisasiorganisasi nonprofit untuk menggalang dana online sebagai tambahan dari penggalangan dana yang mereka lakukan secara offline itu (Dresner, 2014). Pada awal kemunculan internet, orang-orang masih memiliki kekhawatiran untuk bertransaksi online, tetapi seiring dengan meningkatnya pengalaman dan kepercayaan mereka terhadap transaksi online, organisasi-organisasi nonprofit dapat semakin memanfaatkan internet untuk menjangkau lebih banyak donatur dengan jangkauan geografis, sektor, dan kepentingan yang lebih luas (Dresner, 2014).

Kemunculan beragam situs-situs web sosial pada era Web 2.0 juga ikut mendorong peningkatan pengadopsian crowdfunding (Dresner, 2014). Pada era Web 1.0, orang hanya menggunakan web untuk mencari informasi dan melakukan transaksi, tetapi setelah beragam situs-situs web sosial bermunculan pada era Web 2.0, web juga menjadi tempat untuk berbagi 
kesenangan, berkomunikasi dengan teman, dan membangun hubungan secara online dengan orang-orang yang bahkan tidak pernah ditemui (Dresner, 2014). Situs-situs web sosial tidak hanya memungkinkan orang untuk melakukan donasi, tetapi juga memungkinkan amplifikasi kekuatan kegiatan penggalangan dana tersebut dengan cara memudahkan orang untuk menyebarkan informasi tentang kegiatan penggalangan dana itu supaya orang-orang yang berada dalam jaringan sosial mereka terinformasi mengenai apa yang mereka percayai dan menjadi tertarik untuk ikut berpartisipasi (Dresner, 2014).

Seiring dengan perkembangan teknologi, semakin banyak teknologi yang dapat dimanfaatkan untuk melaksanakan kegiatan crowdfunding. Teknologiteknologi yang beragam itu semakin lama semakin berkonvergensi. Konvergensi berarti merampingkan berbagai macam teknologi yang berbeda menuju ke satu arah (Trivedi \& Thaker, 2001). Sebelum era konvergensi media, satu teknologi hanya digunakan untuk satu aplikasi dan satu tujuan spesifik (Trivedi \& Thaker, 2001), misalnya telepon hanya untuk menelepon dan televisi hanya untuk menonton tayangan televisi. Revolusi digital memungkinkan beragam media untuk melepaskan identitasnya dan bergabung dengan media lain dengan tujuan yang sama, yaitu untuk mentransmisikan dan memanipulasi informasi, misalnya melalui penggabungan teks, gambar diam, gambar bergerak, suara, dan mesin pencarian di satu medium (Chakaveh \& Bogen, 2007; Trivedi \& Thaker, 2001). Kemunculan teknologiteknologi baru mendorong penyediaan layanan yang lebih murah, nyaman, padat, dan mudah digunakan (Trivedi \& Thaker, 2001).

Konvergensi media memberikan dampak signifikan ke masyarakat, seperti perubahan gaya hidup, pola perilaku, dan strategi pasar (Trivedi \& Thaker, 2001). Konvergensi media dapat menjangkau bagian dari masyarakat yang sebelumnya tidak dapat dijangkau, misalnya orang yang memiliki keterbatasan fisik dan tidak dapat bepergian jauh (Trivedi \& Thaker, 2001). Hal tersebut memungkinkan peningkatan partisipasi masyarakat. Masyarakat menjadi lebih terinformasi karena akses ke informasi yang semakin luas dan keinteraktifan yang dimungkinkan oleh konvergensi media (Trivedi \& Thaker, 2001).

Menurut Chakaveh dan Bogen (2007), dari sisi ekonomi, ada beberapa strategi konvergensi media yang digunakan oleh perusahaan untuk mendapatkan keuntungan finansial, yaitu:

1) Konsentrasi korporasi di mana beberapa perusahaan besar memiliki banyak media.

2) Digitalisasi di mana konten media diproduksi dalam sebuah bahasa komputer yang universal sehingga dapat dengan mudah diadaptasi untuk penggunaan di berbagai medium.

3) Deregulasi pemerintah di mana para konglomerat media semakin diizinkan untuk memiliki berbagai macam media di dalam pasar yang sama dari hulu ke hilir.

Konvergensi media pada industri crowfunding lebih menggunakan strategi digitalisasi konten di mana konten dapat dengan mudah diadaptasi ke berbagai medium sehingga memudahkan akses ke konten tersebut. Konvergensi media tersebut dapat dilihat pada tahap produksi 
dan distribusi, serta dari sisi penyedia platform crowdfunding, seperti Kitabisa, dan dari sisi penggalang dana atau pemilik kampanye.

Pada tahap produksi, konvergensi media dari sisi penggalang dana dapat dilihat dari penggunaan berbagai macam bentuk media, seperti teks tertulis, foto atau grafis, dan video untuk menarasikan cerita mengenai latar belakang penggalangan dana dan rencana penggunaan uang donasi. Misalnya, Dompet Dhuafa menggunakan teks, fotofoto dokumentasi kegiatan penyemprotan desinfektan, dan infografis rencana penerima bantuan dan jenis bantuan dalam narasi di laman penggalangan dana mereka (https://kitabisa.com/campaign/ayolawanc orona) yang merupakan bagian dari kampanye \#BersamaLawanCorona di platform Kitabisa. Penggunaan ragam bentuk media itu akan menambah kejelasan dan keefektifan dari narasi kampanye crowdfunding. Tulisan membantu merangkai cerita keseluruhan bagi pembaca, sedangkan foto atau grafis dan video menjadi sarana efektif untuk menarik perhatian dan menjelaskan konsep yang abstrak (Choy \& Schlagwein, 2016). Selanjutnya, distribusi informasi mengenai kampanye crowdfunding dapat dilakukan oleh penggalang dana melalui radio, surat kabar, dan media sosial (Choy \& Schlagwein, 2016).

Dari sisi penyedia platform crowdfunding, tahap produksi berarti memproduksi atau menyediakan platform yang dapat mendukung pelaksanaan crowdfunding. Dukungan tersebut dilakukan antara lain dengan cara menyediakan platform yang mendukung penggunaan beragam bentuk media dalam penjelasan detail kampanye crowdfunding, menyediakan beragam metode pembayaran bagi para donatur yang ingin melakukan donasi secara offline dan online, membuat alur proses donasi yang mudah, dan menyediakan fitur untuk mempermudah distribusi konten. Praktik konvergensi media di tahap produksi itu dapat ditemukan di platform crowdfunding Kitabisa. Platform Kitabisa mengakomodasi penambahan foto dan video di penjelasan detail kampanye dan perkembangan kabar terbaru kampanye. Kitabisa juga menyediakan beragam pilihan metode pembayaran, mulai dari uang digital, transfer rekening, hingga kartu kredit di mana semua metode pembayaran itu dapat dilakukan di mana saja dan kapan saja melalui telepon genggam. Proses donasi semakin dimudahkan dengan pilihan untuk berdonasi tanpa harus memiliki akun di Kitabisa sehingga donatur tidak harus repot mengingat kata sandi setiap kali mereka ingin melakukan donasi. Pembuatan platform yang mudah diakses dan digunakan seperti itu menjadi salah satu faktor kesuksesan sebuah kampanye crowdfunding karena kemudahan proses memberikan donasi ikut menentukan keputusan orang untuk ikut berdonasi (Choy \& Schlagwein, 2016).

Tahap distribusi atau penyebaran informasi dapat dipermudah oleh penyedia platform crowdfunding dengan menambahkan tombol fungsi berbagi ke media sosial sehingga pemilik kampanye atau para donator dapat dengan mudah membagikan kampanye crowdfunding itu ke jaringan sosial mereka. Platform Kitabisa menyediakan tombol berbagi ke WhatsApp di laman kampanye dan tombol berbagi ke WhatsApp dan Facebook di laman pembayaran donasi. 
Kemudahan akses ke informasi crowdfunding di platform juga menjadi hal yang penting untuk diperhatikan. Pertumbuhan penggunaan teknologi mobile harus menjadi pertimbangan untuk memastikan pengguna mobile dapat dengan mudah mengakses platform crowdfunding. Wong (2012) menyebutkan bahwa ada dua pendekatan untuk beradaptasi dengan teknologi mobile, yaitu (1) melalui pembuatan aplikasi untuk sistem operasi mobile tertentu, seperti Android dan iOS, dan (2) melalui pembuatan situs web versi mobile. Platform crowdfunding Kitabisa memiliki desain situs yang dapat beradaptasi dengan ukuran layar sehingga dapat diakses secara optimal di tablet dan telepon genggam. Selain itu, Kitabisa juga memiliki aplikasi mobile untuk sistem operasi iOS dan Android.

\section{Crowdfunding sebagai Bentuk Budaya Partisipatif}

Budaya partisipatif adalah budaya yang memiliki hambatan relatif rendah bagi terbentuknya ruang yang memungkinkan ekspresi artistik, keterlibatan masyarakat, dukungan kuat untuk menciptakan dan membagikan kreasi, dan bimbingan informal di mana partisipan yang lebih berpengalaman membagikan pengetahuan mereka kepada partisipan baru (Jenkins et al., 2009). Dalam budaya partisipatif, para partisipan merasa bahwa kontribusinya berharga dan merasa terkoneksi secara sosial dengan para partisipan yang lainnya (Jenkins et al., 2009). Tidak semua orang harus terlibat, tetapi semua orang harus percaya bahwa mereka bebas untuk ikut berkontribusi dan ketika mereka berkontribusi, kontribusi mereka itu akan dihargai oleh orang lain (Jenkins et al., 2009).

Studi mengenai media baru sering kali berfokus pada teknologi dan apa yang dapat dilakukan dengan teknologi itu (Jenkins et al., 2009). Namun, bagi Jenkins dkk. (2009), pengguna adalah hal yang lebih penting karena teknologi, seperti komputer, tidak dapat melakukan apa pun tanpa adanya pengguna. Ada konteks budaya dan institusional tertentu yang menentukan bagaimana dan mengapa teknologi itu digunakan. Kemunculan teknologi baru mengubah hubungan manusia dengan teknologi yang sudah ada sebelumnya dan aktivitas yang terkait, tetapi aktivitas tersebut hanya akan menyebar jika budaya mendukung terjadinya penyebaran tersebut (Jenkins et al., 2009). Budaya partisipatif muncul karena budaya menyerap dan merespon kemunculan teknologi-teknologi media baru yang memungkinkan orang biasa untuk mengarsipkan, menganotasi, menyediakan, dan mensirkulasi konten media dengan cara baru yang lebih kuat dan berpengaruh (Jenkins et al., 2009).

Menurut Jenkins dkk. (2009), budaya partisipatif memiliki empat bentuk, yaitu:

1) Afiliasi atau keanggotaan informal maupun informal di komunitaskomunitas online yang berkisar pada beragam bentuk media, seperti Facebook, Twitter, online games, forum, dan WhatsApp.

2) Ekspresi melalui pembuatan sebuah bentuk kreasi baru, seperti membuat cerita fan fiction, video penggemar, dan modding untuk video games.

3) Pemecahan masalah secara kolaboratif dalam kelompok informal maupun formal untuk menyelesaikan tugas dan 
membentuk sebuah pengetahuan baru, misalnya kolaborasi membuat artikel pengetahuan di Wikipedia.

4) Sirkulasi atau menentukan alur informasi dalam media baru sehingga dapat membentuk tren baru, seperti podcasting dan blogging.

Budaya partisipatif dalam crowdfunding dapat dilihat dari partisipasi para aktor yang terlibat di dalamnya. Pelaksanaan crowdfunding melalui internet saat ini pada dasarnya memiliki konsep yang sama dengan praktik penggalangan dana untuk membiayai sesuatu yang telah dilakukan ribuan tahun yang lalu (Dresner, 2014). Orang-orang ingin terlibat dalam penggalangan dana tersebut karena mereka percaya pada hal yang mereka danai, ingin ikut memberikan kontribusi, ingin menjadi bagian dari sejarah, dan ingin menjadi bagian dari sesuatu yang lebih besar dari diri mereka sendiri (Dresner, 2014). Alasan yang sama juga mendasari orangorang untuk ikut terlibat dalam crowdfunding pada era sekarang (Choy \& Schlagwein, 2016; Dresner, 2014).

Teknologi-teknologi yang ada pada saat ini menyediakan sarana untuk menjangkau dan berkolaborasi dengan khalayak dalam jumlah besar atau crowd dan memungkinkan penyebaran informasi mengenai sebuah kampanye individual secara efisien (Dresner, 2014). Penggunaan beragam teknologi memungkinkan pemenuhan keinginan khalayak untuk ikut terlibat, mendukung, membuat, dan mengambil keputusan terkait dengan kampanye crowdfunding (Dresner, 2014).

Partisipasi pengguna menjadi sebuah faktor kunci bagi kesuksesan sebuah kampanye crowdfunding (Kim, Por, \& Yang, 2017). Masyarakat didorong untuk membagikan kampanye tersebut ke jaringan sosial online mereka sehingga tercipta kepedulian mengenai kampanye tersebut di berbagai media sosial (Choy \& Schlagwein, 2016). Ketersediaan tombol berbagi ke WhatsApp dan Facebook di platform Kitabisa membantu mempermudah penyebaran informasi mengenai kegiatan kampanye \#BersamaLawanCorona ke jejaring sosial yang lebih luas. Selain itu, penggunaan tanda pagar \#BersamaLawanCorona sebagai nama kampanye di platform Kitabisa juga dapat digunakan untuk mempermudah orang untuk menemukan kampanye-kampanye crowdfunding dan kegiatan-kegiatan terkait lainnya di media sosial sehingga memudahkan mereka untuk ikut berpartisipasi dalam usaha kolaboratif menangani masalah pandemi Covid-19. Hasil penelusuran tagar \#BersamaLawanCorona di Twitter dan Instagram menunjukkan tagar tersebut antara lain digunakan untuk mengajak berdonasi, mencari penyedia alat-alat perlindungan diri, dan meminta bantuan donasi seperti yang dapat dilihat pada 

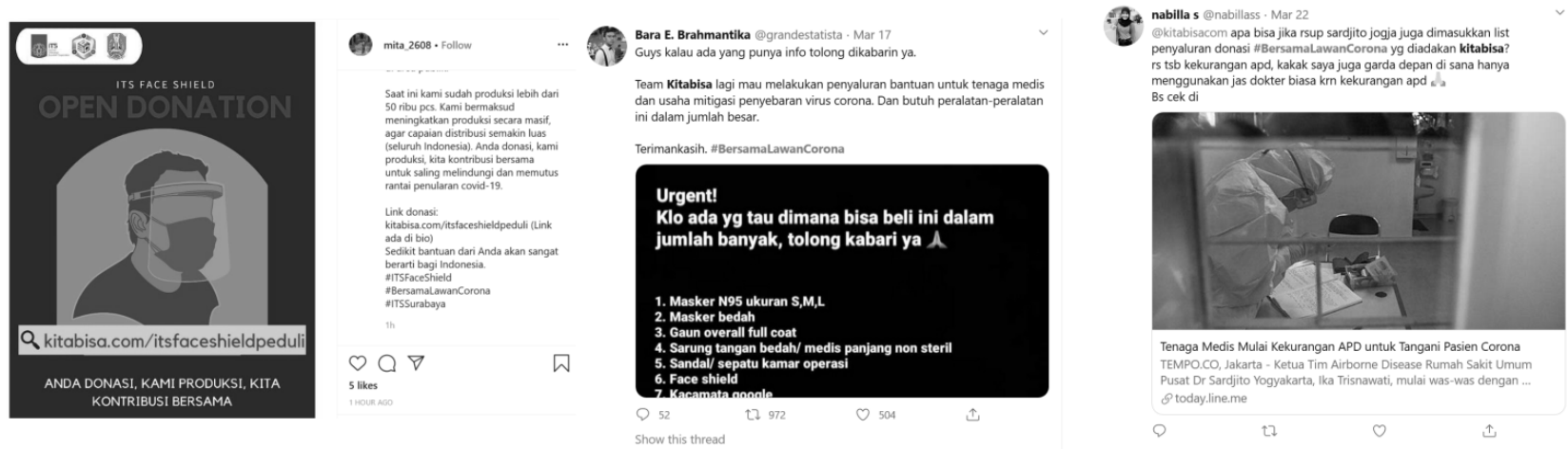

Gambar 1.

Sumber: Instagram dan Twitter

\section{Gambar 1. Contoh Penggunaan Tagar \#BersamaLawanCorona di Media Sosial}

Komentar dari para donatur di laman kampanye juga membantu memengaruhi orang lain untuk ikut terlibat dalam kampanye crowdfunding (Choy \& Schlagwein, 2016; Kim et al., 2017). Donasi yang dilakukan oleh orang lain menjadi salah satu motivasi untuk ikut berdonasi karena jumlah donatur yang banyak dianggap sebagai indikator bahwa kampanye tersebut layak untuk diperhatikan (Choy \& Schlagwein, 2016). Kemampuan untuk melihat progres kampanye, seperti berapa banyak uang yang sudah terkumpul, siapa saja yang sudah menyumbang, dan kemampuan untuk membaca komentar para donatur dapat meningkatkan motivasi orang untuk ikut menyumbang karena mereka ingin menjadi bagian dari komunitas yang memiliki pikiran dan nilai yang sama (Choy \& Schlagwein, 2016). Komentar dari para donatur dan pemilik kampanye itu membuat mereka merasa menjadi bagian dari komunitas yang saling terhubung meskipun terpisah jarak dan waktu (Choy \& Schlagwein, 2016).

Pada offline crowdfunding, progres kampanye berupa jumlah dana yang terkumpul dan nama donatur biasanya diumumkan dalam sebuah pertemuan berkala atau media massa. Pada online crowdfunding, progres tersebut dapat dilihat pada platform crowdfunding yang digunakan. Misalnya pada platform crowdfunding Kitabisa, orang dapat melihat progres dana yang terkumpul, kabar terbaru dari penggalang dana, siapa saja fundraiser atau pihak yang membantu menggalang dana, siapa saja donatur dan berapa besar donasi yang mereka berikan, berapa jumlah orang yang sudah berdonasi, waktu donasi, dan komentar dari para donatur. Keberadaan informasi tersebut dapat menunjukkan tingkat keaktifan kampanye crowdfunding itu dan dapat semakin meningkatkan rasa kebersamaan yang mendorong orang untuk ikut berpartisipasi dalam suatu kampanye.

\section{Pemanfaatan Crowdfunding pada Masa Pandemi Covid-19}

Badan Kesehatan Dunia atau WHO (World Health Organization) menetapkan Coronavirus disease (Covid-19) atau yang terkadang disebut sebagai virus korona menjadi pandemi global pada 11 Maret 2020 (Dzulfaroh, 2020). Penetapan status pandemi global tersebut dikarenakan Covid-19 telah menyebar ke 118 negara dengan jumlah kasus positif dan korban 
meninggal dunia yang terus meningkat (Dzulfaroh, 2020). Dengan penetapan status pandemi global tersebut, negaranegara di seluruh dunia diharapkan lebih serius menangani dan mencegah penyebaran Covid-19 (Dzulfaroh, 2020).

Kasus pertama positif Covid-19 di Indonesia diumumkan pada 2 Maret 2020 oleh Presiden Joko Widodo (CNN Indonesia, 2020). Setelah pengumuman tersebut, banyak orang mulai membeli masker dan hand sanitizer atau cairan pembersih tangan untuk mencegah penularan Covid-19 (DP, 2020). Permintaan yang tinggi mengakibatkan kelangkaan stok masker dan hand sanitizer di pasar dan peningkatan harga jual yang drastis. Selain masker dan hand sanitizer, alat-alat kesehatan lainnya, seperti termometer tembak, alkohol, dan antiseptik juga mengalami kelangkaan stok dan peningkatan harga (Safhira, 2020). Hal itu berdampak pada para tenaga medis yang menjadi kesulitan untuk memperoleh alat-alat kesehatan tersebut, padahal mereka adalah pihak yang paling membutuhkan alat-alat tersebut karena mereka berhadapan langsung dengan pasien positif sehingga menjadi pihak yang paling rawan tertular. Masalah tersebut semakin diperparah oleh semakin banyaknya jumlah pasien positif yang harus ditangani oleh para tenaga medis.

Di tengah situasi tersebut, muncul beragam aksi penggalangan dana untuk membantu tenaga medis mendapatkan alat-alat kesehatan atau alat perlindungan diri (APD). Beberapa kampanye penggalangan dana tersebut memanfaatkan platform crowdfunding Kitabisa. Terdapat kampanye besar penggalangan dana terkait epidemi Covid-19 di Kitabisa yang menggunakan
\#BersamaLawanCorona.

Kampanye

\#BersamaLawanCorona

itu

diselenggarakan oleh Kitabisa dan mitra.

Mitra atau yang disebut dengan istilah partners pada platform Kitabisa terdiri atas individu, LSM, tokoh publik, komunitas, yayasan, perusahaan, dan organisasi lainnya. Setiap partners mengadakan kampanye sendiri dengan target yang dapat berbeda antara satu sama lain, tetapi masih dalam topik yang sama, yaitu bersama melawan korona. Ada kampanye penggalangan dana bagi para tenaga medis untuk mendapatkan APD dan makanan. Ada juga kampanye penggalangan dana untuk membantu para pekerja informal, seperti pengemudi ojek dan pedagang kaki lima, yang tidak dapat bekerja dari rumah atau yang pendapatannya menurun karena kebijakan bekerja dari rumah.

Dari kampanye crowdfunding \#BersamaLawanCorona, kita dapat melihat empat bentuk budaya partisipatif, yaitu afiliasi, ekspresi, pemecahan masalah secara kolaboratif, dan sirkulasi. Penggunaan judul besar kampanye \#BersamaLawanCorona menyatukan kampanye-kampanye crowdfunding terkait bantuan selama masa pandemi Covid-19 dalam satu bendera dan menciptakan sebuah kebersamaan untuk satu tujuan, yaitu melawan korona. Orang dapat memilih partners mana yang merupakan afiliasi mereka, misalnya penggemar tokoh publik tertentu dapat memilih untuk melakukan donasi ke kampanye crowdfunding yang diselenggarakan oleh tokoh publik tersebut supaya merasakan kedekatan dengan tokoh tersebut dan orang-orang yang sama-sama menggemari tokoh itu sehingga dapat tercipta rasa kebersamaan yang semakin erat di dalam komunitas penggemar. Partisipasi dalam 
bentuk ekspresi dapat dilakukan dengan membuat artikel blog mengenai pengalamannya terlibat dalam sebuah aksi sosial bersama dengan komunitas atau ikut serta membantu membuat materi promo untuk kampanye crowdfunding itu. Keikutsertaan berdonasi pada kampanye crowdfunding yang diadakan oleh kelompok yang menjadi afiliasinya merupakan salah satu bentuk pemecahan masalah secara kolaboratif, yaitu mengenai pencarian solusi terkait masalah finansial dalam masa pandemi Covid-19. Kampanye besar berjudul \#BersamaLawanCorona yang menaungi kampanye-kampanye penggalangan dana untuk penanganan masalah selama masa pandemi Covid-19 membuka kesempatan bagi masyarakat untuk berkolaborasi menangani masalah korona dengan komunitas-komunitas lain di luar afiliasinya. Kolaborasi tersebut dapat terjadi atas dasar kesamaan nilai atau tujuan, yaitu melawan korona.

Bentuk budaya partisipatif lainnya adalah sirkulasi atau penyaluran informasi di media baru. Penyebaran informasi mengenai kampanye crowdfunding \#BersamaLawanCorona dapat dilakukan melalui beragam saluran komunikasi.
Penyelenggara crowdfunding, seperti tokoh publik atau LSM, dapat menyebarkan informasi mengenai kampanye crowdfunding mereka melalui situs web, blog, video YouTube, media sosial, dan media massa. Para donator membagikan informasi melalui media sosial ke jaringan sosial mereka. Platform crowdfunding Kitabisa juga turut memfasilitasi penyebaran informasi melalui penyediaan tombol berbagi ke aplikasi chatting WhatsApp, posting rutin di media sosial mereka, dan kerja sama liputan dengan media massa.

Salah satu tokoh publik yang ikut terlibat menggalang dana dalam kampanye \#BersamaLawanCorona di platform Kitabisa adalah artis Raffi Ahmad dan keluarga. Raffi Ahmad berhasil mengumpulkan dana lebih dari 1 milyar dalam waktu seminggu (Janati, 2020). Keterlibatan Raffi Ahmad beserta istrinya, Nagita Slavina, dalam penggalangan dana itu mendapatkan sorotan di media massa, seperti di portal berita online Kompas dan di acara berita televisi CNN Indonesia yang rekamannya kemudian diunggah ke YouTube (Gambar 2).
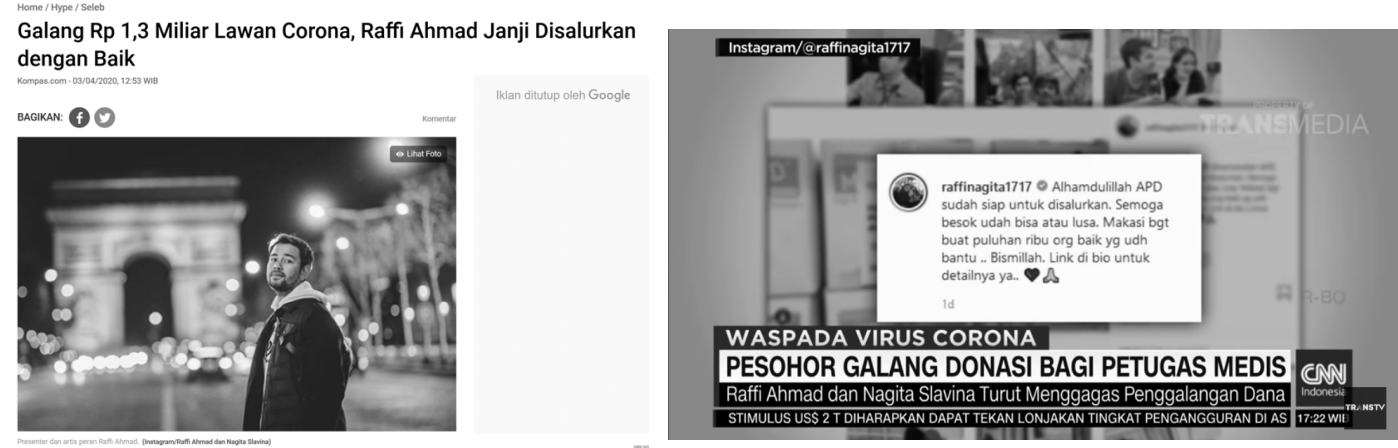

Sumber: Kompas dan CNN Indonesia

Gambar 2. Liputan Penggalangan Dana Raffi Ahmad di Media Massa

Liputan di media massa itu turut menyebarluaskan informasi mengenai kegiatan penggalangan dana yang dilakukan oleh Raffi Ahmad di platform 
Kitabisa. Liputan-liputan itu mengamplifikasi usaha keluarga Raffi Ahmad menyebarkan informasi penggalangan dana yang ia lakukan melalui akun-akun media sosial yang mereka miliki. Melalui media sosial, keluarga Raffi Ahmad membagikan informasi penggalangan dana dan tautan

ke laman kampanye mereka di platform Kitabisa (Gambar 3). Selain itu, mereka menggunakan media sosial untuk membagikan video dan foto-foto perkembangan terbaru mengenai kegiatan penggalangan dana mereka (Gambar 4) sebagai tambahan dari laporan yang mereka berikan di platform Kitabisa.

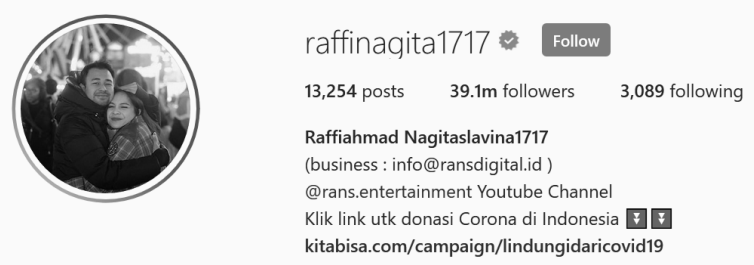

RANS@raffi_nagita17· Mar 23

Alhamdullilah melalui @kitabisacom udh ngumpulin 600juta lebih dan terus bertambah buat membantu tenaga medis kita yg sedang berjuang melawan Corona

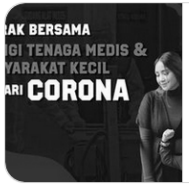

Klik untuk donasi - Lindungi Tenaga Medis dan Masy... Tenaga Kesehatan, Driver Ojol dan Pedagang Keliling tak bisa bekerja dari rumah, ayo kita donasi bantu ... (P) kitabisa.com

Q $207710 \quad 074$

Sumber: Instagram dan Twitter

Gambar 3. Penyebaran Informasi melalui Akun Media Sosial
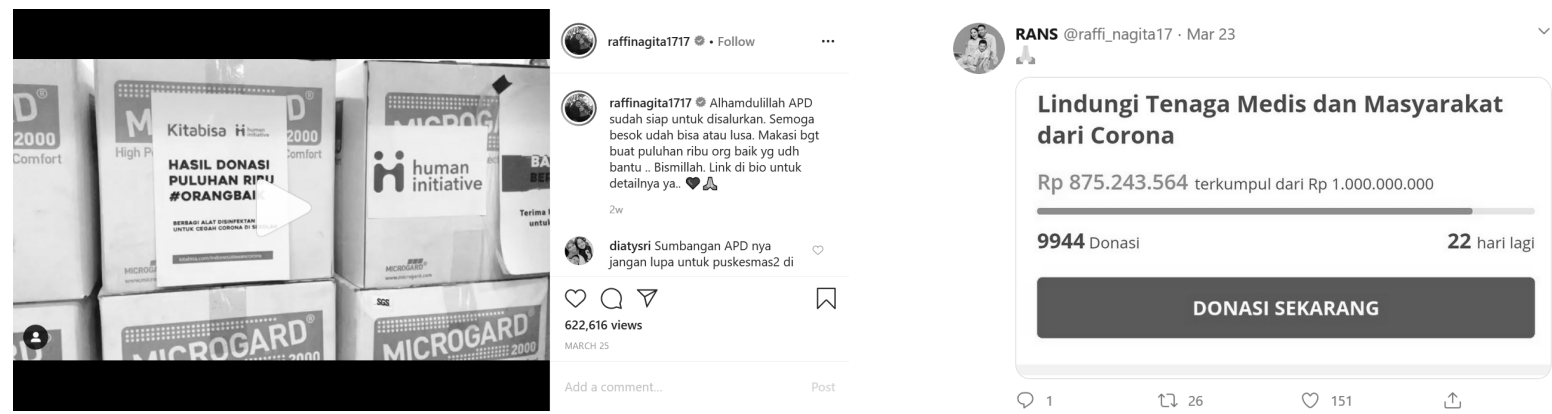

Sumber: Instagram dan Twitter

Gambar 4. Laporan Perkembangan melalui Akun Media Sosial

Media sosial juga digunakan oleh Raffi Ahmad dan Nagita Slavina untuk berinteraksi dengan masyarakat secara langsung. Hal itu terlihat dari tweet mereka yang berisi ucapan terima kasih kepada pihak-pihak yang telah ikut berdonasi. Akun Twitter Raffi Ahmad juga terlihat me-retweet tweet orang yang meminta bantuan masker, hand sanitizer, dan alatalat perlindungan diri lainnya. Interaksiinteraksi seperti itu mendorong masyarakat untuk ikut berpartisipasi dalam menyebarkan informasi mengenai penggalangan dana yang dilakukan oleh keluarga Raffi Ahmad, antara lain dengan membuat tweet yang mengajak orang berdonasi melalui kampanye crowdfunding Raffi Ahmad di Kitabisa dan ikut memberikan informasi pihak-pihak mana saja yang sedang membutuhkan bantuan melalui kolom komentar atau mention di Twitter.

Kegiatan online crowdfunding yang dilakukan oleh keluarga Raffi Ahmad itu 
juga didukung oleh penyebaran informasi secara offline yang dilakukan saat menyalurkan bantuan dari hasil donasi sementara yang terkumpul. Penyebaran informasi tersebut dilakukan dengan mencantumkan nama kegiatan, nama akun media sosial, dan tautan ke laman donasi milik keluarga Raffi Ahmad di platform Kitabisa (Gambar 5). Kegiatan-kegiatan offline tersebut kemudian difoto dan diunggah ke laman laporan perkembangan kampanye mereka di platform Kitabisa sehingga terjadi penguatan reputasi dan kredibilitas penggalang dana secara offline dan online. Hal itu dapat berpengaruh pada peningkatan kepercayaan dan keinginan orang untuk berdonasi, seperti yang dikatakan oleh Gras dkk. (2017) bahwa penggunaan platform offline dan online secara bersamaan akan membangun sebuah komunitas yang lebih kuat dan hal itu dapat meningkatkan kemungkinan orang untuk berdonasi karena orang cenderung ingin berdonasi untuk membangun hubungan dengan orang lain.
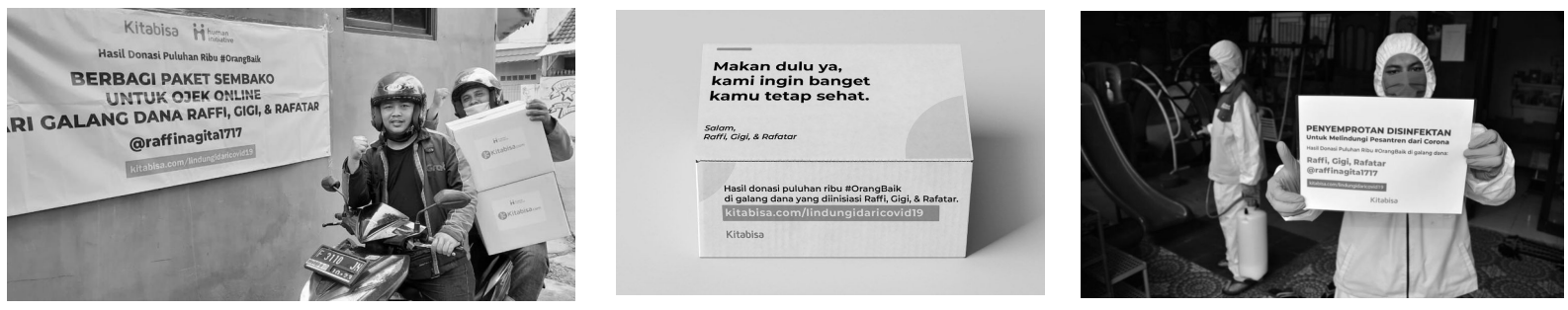

Sumber: Kitabisa

Gambar 5. Kegiatan Penyaluran Bantuan Offline

Hingga 12 April 2020, kampanye crowdfunding \#BersamaLawanCorona telah berhasil mengumpulkan dana 101 milyar lebih dari 3.300 kampanye lebih. Pencapaian tersebut akan sulit dilaksanakan tanpa bantuan teknologi digital dan internet. Teknologi digital dan internet memungkinkan informasi tersebar dengan lebih cepat dan luas tanpa hambatan waktu sehingga membuka peluang semakin banyak orang untuk ikut berpartisipasi dalam kampanye crowdfunding \#BersamaLawanCorona. Ketersediaan beragam cara akses informasi pada platform Kitabisa, seperti melalui situs web versi desktop dan mobile, serta aplikasi mobile untuk iOS dan Android, memudahkan masyarakat untuk mendapatkan informasi mengenai kampanye crowdfunding itu. Orang dapat dengan mudah mengakses informasi mengenai progres dana yang terkumpul, tenggat waktu pelaksanaan kampanye, cerita latar belakang dan tujuan penggalangan dana, informasi terbaru dari penggalang dana mengenai pencairan dana dan penyaluran dana, siapa saja donatur, berapa besar donasi setiap donatur, waktu berdonasi, dan komentar-komentar dari para donatur. Informasi tersebut mengesankan keterbukaan sehingga memunculkan perasaan keterlibatan nyata dalam sebuah aksi kolaboratif untuk satu tujuan bersama yang pada akhirnya dapat mendorong semakin banyak orang untuk ingin berpartisipasi. Hal itu ditambah dengan keaktifan platform crowdfunding Kitabisa, penggalang dana, dan donatur dalam menyebarkan informasi ke jaringan sosial mereka melalui media sosial, media 
massa, dan sarana komunikasi lainnya. Selain itu, kemudahan alur proses donasi pada platform Kitabisa, seperti kemampuan berdonasi tanpa harus membuat akun di Kitabisa terlebih dulu dan ketersediaan beragam pilihan metode pembayaran baik online maupun offline, juga mendukung pelaksanaan kampanye crowdfunding \#BersamaLawanCorona.

\section{SIMPULAN}

\section{Perkembangan}

teknologi memunculkan keragaman media digital pada era internet. Beragam media itu berkonvergensi dan dapat dimanfaatkan untuk satu tujuan, antara lain untuk kegiatan penggalangan dana atau crowdfunding. Pemanfaatan beragam teknologi yang tersedia pada era konvergensi media memungkinkan partisipasi khalayak dalam jumlah besar secara cepat di dalam kegiatan crowdfunding tanpa adanya hambatan jarak geografis. Kecepatan dan kemudahan berpartisipasi dalam penggalangan dana sangat diperlukan, terutama pada saat menghadapi krisis pandemi Covid-19 di mana waktu menjadi salah satu faktor yang harus diperhatikan agar virus tidak semakin menyebar.

Pemanfaatan teknologi untuk menyukseskan kampanye crowdfunding didukung oleh budaya partisipatif yang telah terbentuk di dalam masyarakat. Satu nilai atau tujuan bersama dapat memicu partisipasi dari berbagai lapisan masyarakat untuk turut memanfaatkan beragam teknologi yang tersedia guna menyukseskan aksi penggalangan dana.

Ketika hendak melakukan kegiatan crowdfunding, penggalang dana perlu memperhatikan pemilihan platform crowdfunding yang tepat, baik dari segi kesamaan nilai yang diusung di dalam platform tersebut, tipe pendanaan, teknologi dan format media yang didukung, hingga alur kemudahan donasi. Selain itu, penggalang dana juga perlu memperhatikan penggunaan media sosial, media massa, dan sarana komunikasi lainnya, baik offline maupun online, untuk menyebarkan informasi sehingga dapat memperoleh perhatian dan memicu keinginan khalayak untuk ikut berpartisipasi dalam kegiatan penggalangan dana tersebut. Informasi mengenai latar belakang kegiatan penggalangan dana dan laporan perkembangan kegiatan perlu diberikan secara transparan dan jelas melalui penggunaan berbagai format media yang mendukung, seperti teks, foto, dan video supaya khalayak dapat lebih percaya dengan reputasi dan kredibilitas penggalang dana dan semakin tertarik untuk ikut berpartisipasi.

Tulisan ini diharapkan dapat memberikan sumbangan terhadap bidang ilmu komunikasi dengan menjadi rujukan awal bagi penelitian-penelitian selanjutnya yang ingin menggunakan konsep crowdfunding, budaya partisipatif, dan konvergensi media. Penelitian selanjutnya dapat dilakukan dengan memperkuat data empiris, misalnya mencoba menyoroti narasi yang digunakan dalam sebuah kampanye crowdfunding yang menggunakan beragam media dengan menggunakan metode analisis wacana atau meneliti pola perilaku para partisipan dalam sebuah kampanye crowdfunding dengan menggunakan metode etnografi untuk menemukan narasi atau pola yang tepat digunakan untuk kegiatan crowdfunding di era konvergensi media ini supaya kegiatan crowdfunding itu dapat 
memancing partisipasi khalayak secara lebih luas dan memperoleh hasil yang lebih maksimal.

\section{UCAPAN TERIMA KASIH}

Penulis mengucapkan terima kasih kepada Inaya Rakhmani, S.Sos., M.A., Ph.D., yang telah memberikan masukan mengenai topik penulisan serta dosendosen lainnya di Program Pascasarjana, Departemen Ilmu Komunikasi, FISIP, Universitas Indonesia yang telah berbagi ilmunya selama ini sehingga penulis dapat menulis artikel ini. Ucapan terima kasih juga ingin penulis sampaikan kepada redaksi Jurnal Avant Garde dan reviewer yang telah meluangkan waktu dan memberikan masukan selama proses review.

\section{DAFTAR PUSTAKA}

Abdillah, F., \& Danial, E. (2015). Crowdfunding: Demokratisasi Akses Keuangan dalam Mendukung Aksi Sosial Mahasiswa. Jurnal Ilmiah Mimbar Demokrasi, 15(1).

Adiansah, W., Mulyana, N., \& Fedryansyah, M. (2016). Potensi Crowdfunding di Indonesia dalam Praktik Pekerjaan Sosial. In Prosiding KS: Riset \& PKM (hal. 155-291).

Arifin, S. R., \& Wisudanto. (2017). Crowdfunding sebagai Alternatif Pembiayaan Pembangunan Infrastruktur. In Prosiding Simposium II - UNIID (hal. 309-314). Palembang.

Aziz, I. A., Nurwahidin, N., \& Chailis, I. (2019). Faktor-Faktor yang Mempengaruhi Masyarakat Menyalurkan Donasi Melalui Platform Crowdfunding Berbasis Online. Jurnal Syarikah, 5(1), 94-108. https://doi.org/10.30997/jsei.v5i1.1835

Belleflamme, P., Lambert, T., \& Schwienbacher, A. (2014). Crowdfunding: Tapping the right crowd. Journal of Business Venturing, 29, 585609.

https://doi.org/10.1016/j.jbusvent.2013.0
7.003

Budiman, T., \& Octora, R. (2019). Perlindungan Hukum Bagi Donatur dalam Kegiatan Donation Based Crowdfunding Secara Online. Jurnal Kertha Patrika, 41(3), 222-237.

Chakaveh, S., \& Bogen, M. (2007). Media Convergence, an Introduction. In Lecture Notes in Computer Science (including subseries Lecture Notes in Artificial Intelligence and Lecture Notes in Bioinformatics) (Vol. 4552 LNCS, hal. 811-814). https://doi.org/10.1007/978-3540-73110-8 88

Chang, S. E. (2018). Regulation of Crowdfunding in Indonesia. Law Review, $X V I I I(1), 41-71$.

Choy, K., \& Schlagwein, D. (2016). Crowdsourcing for a better world: On the relation between IT affordances and donor motivations in charitable crowdfunding. Information Technology \& People, 29(1), 221-247. https://doi.org/10.1108/ITP-09-20140215

CNN Indonesia. (2020). Jokowi Umumkan Dua WNI Positif Corona di Indonesia. Diambil 24 Maret 2020, dari https://www.cnnindonesia.com/nasional/ 20200302111534-20-479660/jokowiumumkan-dua-wni-positif-corona-diindonesia

DP, M. (2020). Masker dan Hand Sanitizer Mahal dan Langka Karena Virus Corona: Awas, Ini Ancaman Penjara bagi Penimbun Masker dan Hand Sanitizer. Diambil 24 Maret 2020, dari https://www.grid.id/read/042047754/mas ker-dan-hand-sanitizer-mahal-danlangka-karena-virus-corona-awas-iniancaman-penjara-bagi-penimbunmasker-dan-hand-sanitizer

Dresner, S. (2014). Crowdfunding: A Guide to Raising Capital on the Internet. New Jersey: John Wiley \& Sons.

Dzulfaroh, A. N. (2020). Virus Corona Jadi Pandemi Global, Apa Dampak dan Langkah Selanjutnya? Diambil 23 Maret 2020 , dari https:/www.kompas.com/tren/read/2020/ 03/12/064800265/virus-corona-jadipandemi-global-apa-dampak-danlangkah-selanjutnya-

Gea, F. D. S. (2016). Crowdfunding: Gerakan Baru Kegotongroyongan di Indonesia (Tinjauan Evolusi Gerakan Aksi Kolektif 
dalam Media Baru). In Prosiding Konferensi Nasional Sosiologi V Asosiasi Program Studi Sosiologi Indonesia. Padang.

Gilson, L. L., \& Goldberg, C. B. (2015). Editors' Comment: So, What Is a Conceptual Paper? Group \& Organization Management, 40(2), 127130.

https://doi.org/10.1177/10596011155764 25

Gleasure, R., \& Feller, J. (2016). Does Heart or Head Rule Donor Behaviors in Charitable Crowdfunding Markets? International Journal of Electronic Commerce, 20(4), 499-524. https://doi.org/10.1080/10864415.2016.1 171975

Gras, D., Nason, R. S., Lerman, M., \& Stellini, M. (2017). Going offline: broadening crowdfunding research beyond the online context. Venture Capital, 19(3), 217237.

https://doi.org/10.1080/13691066.2017.1 302061

Hariyani, I., \& Serfiyani, C. Y. (2015). Perlindungan Hukum Sistem Donation Based Crowdfunding pada Pendanaan Industri Kreatif di Indonesia. Jurnal Legislasi Indonesia, 12(4), 353-361.

Hemer, J. (2011). A snapshot on crowdfunding (No. R2/2011). Karlsruhe. Diambil dari https://www.econstor.eu/bitstream/10419 /52302/1/671522264.pdf

Hutami, N., \& Irwansyah. (2019). Pemanfaatan Aplikasi Mobile Kitabisa dalam Pelaksanaan Crowdfunding di Indonesia. Komunikasi, XIII(2), 183-194.

Ibrahim, N. (2013). Platform Crowdfunding Berbasis Web untuk Donasi, Sponsorship, dan Pendanaan UKM. In Proceedings Konferensi Nasional Sistem Informasi (KNSI) (hal. 216-220). Mataram.

Irfan, M. (2016). Crowdfunding sebagai Pemaknaan Energi Gotong Royong Terbarukan. Share: Social Work Jurnal, 6(1), 1-153.

Janati, F. (2020). Galang Rp 1,3 Miliar Lawan Corona, Raffi Ahmad Janji Disalurkan dengan Baik. Diambil 13 April 2020, dari

https://www.kompas.com/hype/read/202 0/04/03/125316066/galang-rp-13-miliarlawan-corona-raffi-ahmad-janjidisalurkan-dengan-baik?page $=$ all

Jenkins, H., Purushotma, R., Weigel, M., Clinton, K., \& Robison, A. J. (2009).

Confronting the Challenges of Participatory Culture: Media Education for the 21st Century. Cambridge: MIT Press.

Kim, T., Por, M. H., \& Yang, S. (2017). Winning the crowd in online fundraising platforms: The roles of founder and project features. Electronic Commerce Research and Applications, 25, 86-94. https://doi.org/10.1016/j.elerap.2017.09.0 02

Safhira, V. E. (2020). Bagikan Curhatan Tenaga Medis COVID-19 Indonesia yang Kekurangan Alat Memadai, Donna Agnesia: Jangan Sampai Corona Matikan Empati Kita. Diambil 24 Maret 2020, dari https://www.pikiranrakyat.com/entertainment/pr-

01353741/bagikan-curhatan-tenagamedis-covid-19-indonesia-yangkekurangan-alat-memadai-donnaagnesia-jangan-sampai-corona-matikanempati-kita?page $=$ all

Sitanggang, M. H. A. (2018). Memahami Mekanisme Crowdfunding dan Motivasi Berpartisipasi dalam Platform Kitabisa.com. E Journal UNDIP, 23(3), 1-11. Diambil dari https://ejournal3.undip.ac.id/index.php/in teraksi-online/article/view/20859/19553

Trivedi, B., \& Thaker, K. (2001). Social Dimensions of Media Convergence in India. Media Asia, 28(3), 157-162. https://doi.org/10.1080/01296612.2001.1 1726645

Wong, S. H. R. (2012). Which platform do our users prefer: website or mobile app? Reference Services Review, 40(1), 103115. https://doi.org/10.1108/00907321211203 667 